УДК 669

\title{
Progress of Inert Anodes \\ in Aluminium Industry: Review
}

\section{Sai Krishna Padamata, Andrey S. Yasinskiy* and Peter V. Polyakov \\ Siberian Federal University 79 Svobodny, Krasnoyarsk, 660041, Russia}

Received 15.01.2018, received in revised form 26.01.2018, accepted 03.03.2018

The paper is a review of the advancements achieved towards the research work done towards inert anodes for aluminium reduction cell. The research work dedicated towards inert anodes has been for more than a century, but significant advancement was made only a few decades ago. The aim of the researchers was to find the anode which shows excellent electrical conductivity and highly resistant towards corrosion with longer anodic lifetime but this is highly difficult to achieve. This article reviews the research work done on: (1) Ceramics, which are oxides of $\mathrm{Ni}, \mathrm{Sn}, \mathrm{Fe}$, and $\mathrm{Cu}$ which can be one or a combination of oxides e.g. $\mathrm{NiO}-\mathrm{Li}_{2} \mathrm{O}$ (2) Metals, in pure or alloy form (3) Cermets, oxides in combination with the metals. Some results obtained in laboratory scale cells were highly liable and gave a scope to try them on industrial cells.

Keywords: Inert anode, aluminium electrolysis, metallic anode, ceramic anode, cermet anode, lowtemperature electrolysis.

Citation: Padamata S.K., Yasinskiy A.S., Polyakov P.V. Progress of inert anodes in aluminium industry: review, J. Sib. Fed. Univ. Chem., 2018, 11(1), 18-30. DOI: 10.17516/1998-2836-0055.

(C) Siberian Federal University. All rights reserved

* Corresponding author E-mail address: ayasinskiykrsk@gmail.com 


\title{
Инертные аноды
}

\section{в алюминиевой промышленности: обзор}

\author{
С.К. Падамата, А.С. Ясинский, П.В. Поляков \\ Сибирский федеральный университет \\ Россия, 660041, Красноярск, пр. Свободный, 79
}

В статье представлен обзор достижений в разработке инертного анода для алюминиевого электролизера. Исследования, посвященные инертным анодам, проводятся более века, но значительные успехи достигнуты всего несколько десятилетий назад. Целью исследователей была разработка анода с высокими электропроводностью и коррозионной устойчивостью во фторидных расплавах, чего на практике весьма трудно достичь. В этой статье рассмотрень исследования, проведенные на: (1) керамических анодах, содержащих оксидыметаллов $\mathrm{Ni}$, Sn, Fe и Си или их комбинации, например, $\mathrm{NiO}-\mathrm{Li}{ }_{2} \mathrm{O}$; (2) металлах и сплавах (3) керметах, т.е. оксиднометаллических композициях. Некоторые результаты, полученные в лабораторных ячейках, были обнадеживающими и дали возможность проведения промышленных испытаний.

Ключевые слова: инертный анод, электропроводность, коррозия, криолит, ионный расплав, кермет, электролизер.

\section{Introduction}

Hall-Heroult process for aluminium electrowinningis been in use for more than a century to produce aluminium. A lot of advancement was seen in the cell geometry and also the capacity of the cell, where at the being of the process the cell only had the capacity of few thousand amperes and now the cells work at over 400-500 kA. In the process of electrolysis, alumina $\left(\mathrm{Al}_{2} \mathrm{O}_{3}\right)$ is dissolved in molten cryolite at $960{ }^{\circ} \mathrm{C}$ where it decomposes and results in oxygen and liquid aluminium. As aluminium is denser than molten cryolite $\left(\mathrm{Na}_{3} \mathrm{AlF}_{6}\right)$, it deposits at the bottom region of the cell and the oxygen ions react with carbon anode and results in the formation of $\mathrm{CO}_{2}$ according to the equation:

$$
2 \mathrm{Al}_{2} \mathrm{O}_{3 \text { (solution) }}+3 \mathrm{C}_{(\mathrm{s})}=4 \mathrm{Al}_{(\mathrm{l})}+3 \mathrm{CO}_{2(\mathrm{~g})}
$$

But the ideal reaction would be

$$
\mathrm{Al}_{2} \mathrm{O}_{3 \text { (solution) }}=2 \mathrm{Al}_{(\mathrm{l})}+3 / 2 \mathrm{O}_{2(\mathrm{~g})}
$$

which can be achieved by using inert anodes.

Replacing carbon anode with inert anode will eradicate the production of greenhouse gases through the process. De Nora [1] has suggested that the inert anodes should possess the following properties:

- Overvoltage less than $0.5 \mathrm{~V}$ at $0.8 \mathrm{~A} / \mathrm{cm}^{2}$ for oxygen evolution;

- Anode current density, not more than $0.8 \mathrm{~A} / \mathrm{cm}^{2}$;

- High electrical conductivity; 
- Resistance towards fluoridation;

- High chemical stability towards oxygen at $1050^{\circ} \mathrm{C}$;

- Low cost and easy fabrication;

- Ability to form protective oxide scale on the anode (cermets and metals);

- High mechanical strength;

- Easy and stable electrical setup;

- High resistance towards thermal shock;

- Easy maintenance;

- Retrofittable in the present cell design.

The properties described by de Nora are difficult to achieve all at the same time but recent advancements ensure the possibilities of achieving an inert anode. Nevertheless, by using inert anodes, greenhouse gases can be eliminated and it is economically beneficial to use inert anodes as fabrication of consumable carbon anode is expensive.

\section{Ceramics}

Ceramics were the primary interest of researchers because they believed that a ceramics could be potential materials to fabricate inert anode. Ceramics were tested by Belyaev and Studentsov in 1937. Ceramics has the desirable property of low rate of dissolution in molten electrolyte at $960{ }^{\circ} \mathrm{C}$ but they also possess poor electrical conductivity and low mechanical strength.

\section{1. $\mathrm{NiFe}_{2} \mathrm{O}_{4}$ based anodes}

Nickel ferrite was the first ceramic material tested by Alcoa. Du et al. [2] conducted a laboratory scale experiment to know the anodic overvoltage and bubble behaviour of the anode. They discovered that the anodic overvoltage, cell voltage and back EMF can be reduced by the addition of dopants: $0.5 \mathrm{wt} . \% \mathrm{~V}_{2} \mathrm{O}_{5}$ or $1 \mathrm{wt} . \% \mathrm{MnO}_{2}$ or $2.5 \mathrm{wt} . \% \mathrm{TiO}_{2}$. They determined that the electrolytic bubble evolution on the surface of $\mathrm{NiFe}_{2} \mathrm{O}_{4}$ inert anodes, including bubble nucleation, growth, coalescence, growth again, migration and escaping, lasts for 79 seconds whereas for carbon anode it takes 102 seconds. Augustin [3] tested the corrosion behaviour of $\mathrm{NiFe}_{2} \mathrm{O}_{4}$ and stated that the solubility of the $\mathrm{NiFe}_{2} \mathrm{O}_{4}$ inert anode in molten cryolite electrolyte was less and they are stable towards oxidation, stating that the corrosion resistance of the anode was satisfying.

\section{2. $\mathrm{SnO}_{2}$ based anodes}

In the patent Adler [4] stated the behaviour of $\mathrm{SnO}_{2}$ anode, says that the material has a tendency to dissolve slowly in molten cryolite. The solubility of $\mathrm{SnO}_{2}$ anode was also found by Haarberg [5] and was 0.08 wt. $\%$ at $1035^{\circ} \mathrm{C}$. The solubility of the anode can be reduced when the cell will be operated at low temperatures below $780{ }^{\circ} \mathrm{C}$. Adler in his experiment found that the $\mathrm{SnO}_{2}$ shows good chemical stability but lacks good electrical conductivity and haspoor mechanical strength. Addition of dopants like $\mathrm{Sb}_{2} \mathrm{O}_{3}, \mathrm{CuO}, \mathrm{ZnO}, \mathrm{Fe}_{2} \mathrm{O}_{3}$ etc. improves the electrical conductivity and mechanical properties and experiments were performed by adding different compositions of dopants. $\mathrm{SnO}_{2}+2$ wt.\% $\mathrm{Fe}_{2} \mathrm{O}_{3}$ composition was sintered at $1200-1250^{\circ} \mathrm{C}$, for $5 \mathrm{~h}$ and experiments were conducted and was observed that at low anodic current density the corrosion rate was less and contamination of metal was less. A sample with the composition of $\mathrm{SnO}_{2}+1$ wt. $\% \mathrm{Sb}_{2} \mathrm{O}_{3},+2$ wt. $\% \mathrm{Fe}_{2} \mathrm{O}_{3}$ was made and the density was 
improved by $50 \%$ and also electrical conductivity of $220 \mathrm{~S} / \mathrm{cm}$ was obtained. $\mathrm{SnO}_{2}+2$ wt. $\% \mathrm{Sb}_{2} \mathrm{O}_{3}$, $+2 \mathrm{wt} . \% \mathrm{CuO}$ composition has better electrical conductivity of $440 \mathrm{~S} / \mathrm{cm}$. The main backdrop of the anode when it combines with the dopants is the high solubility of dopants in molten cryolite. Dopants leach from the anode at the time of electrolysis and demands for high cell voltage and cause mechanical damage to the anode. The anode with dopants can still be used at low bath temperatures and can have a longer lifetime.

\section{3. $\mathrm{NiO}-\mathrm{Li}_{2} \mathrm{O}$ based anodes}

Laboratory tests were performed by Zaikov [6], and corrosion rate of $\mathrm{NiO}-\left(2.5\right.$ wt.\%) $\mathrm{Li}_{2} \mathrm{O}$ material was determined by keeping the note of the anode's weight while the electrolysis process was going on. He determined that the corrosion rate of the anode can be reduced by increasing the sintering temperature and sintering time during the preparation of the anode, which results in the decrease of anode's porosity. The anode was tested with fluoride meltat $700{ }^{\circ} \mathrm{C}$ for 4.5 hours, and no physical damage to the anode was observed.

\section{Metals}

For many decades, metals have been regarded as the prominent material for the preparation of inert anodes because of its high mechanical strength and good electrical conductivity than ceramics and cermets. Some of the advantages of metal anodes are: good thermal shock resistance, low porosity, easy fabrication into required sizes and shapes, easily electrically connected to the cell. But it also has disadvantages such as poor resistance corrosion, tendency to dissolve in the electrolyte at higher cell operational temperature, expensive than ceramics and cermets.

\subsection{Aluminium bronze}

In laboratory scale experiment, Glucina et al. [11] have investigated two $\mathrm{Cu}-\mathrm{Al}$ alloys which they believed to be potential materials to fabricate anodes for aluminium electrolysis. The anode(AB1) was binary alloy with a composition of $90.25 \mathrm{wt} . \% \mathrm{Cu}, 9.39 \mathrm{wt} . \% \mathrm{Al}$ and little amounts of $0.02 \mathrm{wt} . \%$ $\mathrm{Ni}, 0.10 \mathrm{wt} . \% \mathrm{Fe}$ and impurities of $0.24 \mathrm{wt} . \%$. The Second anode(AB2) was alloyed with $77.81 \mathrm{wt} . \%$ $\mathrm{Cu}, 10.50$ wt.\% Al, 5.10 wt.\% Ni, 4.95 wt.\% Fe and impurities being 1.64 wt.\%. Experiments were performed on anodes $\mathrm{AB} 1$ and $\mathrm{AB} 2$ twice, with and without Al-based oxide scale. It was observed that in $\mathrm{AB} 1$ (no oxide layer or no pre-treated) two oxide layers were formed, the first layer was alumina with a thickness of $500 \mu \mathrm{m}$ and the second layer was Copper oxide with a thickness of $200 \mu \mathrm{m}$. High polarization voltage was obtained in this case. Unlike AB1(no oxide layer), AB2(no oxide layer) was stable and had only one layer formed of Copper oxide. Both the alloys, AB1 and AB2 performed well as an anode with a steady voltage which was operated at a potential of $2.1 \mathrm{~V}$. It was observed that the anodic polarisation was between $0.15-0.2 \mathrm{~V}$ which is lower than the carbon anode. Huge mass loss of the anode at the later stage of electrolysis occurred which leads to anode loss and contamination of metal produced.

\section{2. $\mathrm{Cu}-\mathrm{Ni}-\mathrm{Fe}$ based anodes}

Metallic anodes have the disadvantage of being corrosive but the $\mathrm{Cu}-\mathrm{Ni}-\mathrm{Fe}$ alloy has been showing some good results being less corrosive than the rest of the metal anodes [12, 14-15]. When it comes to 
$\mathrm{Cu}-\mathrm{Ni}-\mathrm{Fe}$ anode, it has the ability to generate a protective surface layer of $\mathrm{NiFe}_{2} \mathrm{O}_{4} \cdot \mathrm{NiFe}_{2} \mathrm{O}_{4}$ layer has a tendency of dissolving slowly in molten cryolite which reduced the anode's corrosion rate. A Cu-Ni-Fe metallic anode was doped with oxygen [16], with composition of $65 \mathrm{wt} . \% \mathrm{Cu}, 20 \mathrm{wt} . \%$ \& $15 \mathrm{wt} . \% \mathrm{Fe}$ and tested at a temperature $\left(700^{\circ} \mathrm{C}\right)$ with potassium cryolite. High corrosion resistance was obtained with a wear rate of $0.8 \mathrm{~cm} /$ year and impurities of $0.2 \mathrm{wt} . \%$ was found in the aluminium metal produced. $\mathrm{Cu}$ metal wt.\% in the alloy places a vital role in the formation of a $\mathrm{NiFe}_{2} \mathrm{O}_{4}$ protective layer and a low percentage of $\mathrm{Cu}$ results in instability of anode in the electrolysis process. Firstly, $\mathrm{CuO}$ layer is formed at the initial stages of electrolysis which acts as a protective layer for $\mathrm{NiFe}_{2} \mathrm{O}_{4}$ inner protective layer of the anode [17]. In the later stages, the $\mathrm{CuO}$ layer dissolves and leads to the contamination of produced aluminium. A study was conducted to overcome these criteria, where $5 \mathrm{wt} . \% \mathrm{Cu}$ was replaced by $(\mathrm{M}=\mathrm{Sn}, \mathrm{Ag}, \mathrm{V}, \mathrm{Nb}, \mathrm{Ir}, \mathrm{Ru})$ and $\mathrm{CuO}$ layer will be replaced by $\mathrm{MO}$, each sample was tested for their respective oxide scale thickness, homogeneity and solubility. The results obtained showed that $\mathrm{Nb}$ was showing promising results with its thick oxide scale and homogeneity [18].

\subsection{De nora metallic inert anode}

Nguyen and de Nora [12] introduced a metallic anode Nickel-Iron based alloy with semi-conductor Nickel-cobalt mixed oxide as an outer coating. Usually, Ni-Fe based alloy is stable towards oxygen due to the formation of nickel ferrite protective scale as an outer layer but nickel is venerable at fluoridation reaction with gaseous aluminium fluoride when it is part of Ni-Fe alloy. In the metal-oxide interface, nickel fluoride layer is formed which is electrically non-conductive. If $\mathrm{Fe}$ content is increased to avoid the fluoridation of $\mathrm{Ni}$, the decrease in oxidation resistance occurs. This scenario can be avoided by coating Ni-Fe anode with Ni-Co coating. This coating acts as a barrier between the Ni-Fe anode and the aluminium fluoride gas, which will avoid the formation of nickel fluoride layer from fluoridation of nickel. The cobalt oxide layer is formed on the Ni-Fe anode which is stable towards the fluoridation and protects the $\mathrm{Ni}$ from forming nickel fluoride. Coming to the experimental procedure, the anode was tested at 100-300 A cell for different durations. At stable conditions, the anode metal core dissolution rate was $2 \mathrm{~mm} / \mathrm{year}$ and the $\mathrm{CoO}$ layer dissolution rate was $3 \mathrm{~mm} / \mathrm{year}$. Estimated anodic lifetime was 1 year with less metal contamination rate of $1340 \mathrm{ppm}$ at laboratory scale and $995 \mathrm{ppm}$ at an industrial scale. The anode surface factor was 2.3 for an industrial anode which is 0.9 less than laboratory anode. With the presence of Co-Ni coating,a thermodynamic penalty of $620 \mathrm{mV}$ versus the carbon anode was observed, but it can be compensated by increasing the active surface of the anode. Overall, anode possessed promising results with high electrical conductivity and good corrosion resistance.

\section{Cermets}

Cermets are a combination of two phases: Ceramics and Metals. Cermets have the desirable properties of both the phases: high electrical conductivity of metals and good chemical stability of ceramics. The use of cermet anodes for aluminium electrolysis was proposed by Alcoa in the 1980s as ceramics were showing poor electrical conductivity.

\section{1. $\mathrm{Fe}-\left(\mathrm{NiFe}_{2} \mathrm{O}_{4}+\mathrm{NiO}\right)$ based anodes}

Ray and Rapp [7-8] patented a cermet anode with a composition of $50 \mathrm{wt} . \% \mathrm{NiO}, 20 \mathrm{wt} . \% \mathrm{Fe}$ and $30 \mathrm{wt} . \% \mathrm{NiFe}_{2} \mathrm{O}_{4}$. The microstructure of the anode's surface area was recorded and it was seen that 
there were nickel ferrite matrix and linearly distributed metallic Fe particles on the anodic surface which resulted in good electrical conductivity of the anode. It was stated that electrical conductivity is varied with respect to the type of preparation. The electrical conductivity of $700 \mathrm{~S} / \mathrm{cm}$ was obtained when hot pressing was performed to prepare the anode. When the composition of iron was reduced from $20 \mathrm{wt} . \%$ to $7 \mathrm{wt} . \%$, drastically low electrical conductivity of $19 \mathrm{~S} / \mathrm{cm}$ was observed. Anode possesses good corrosion resistance with mere contamination of metal produced. At higher anodic current densities, higher current efficiency was achieved and contamination of metal was less. This $\mathrm{Fe}-\left(\mathrm{NiFe}_{2} \mathrm{O}_{4}+\mathrm{NiO}\right)$ anode is the pioneer of the research towards cermet anodes.

\section{2. $\mathrm{Cu}-\mathrm{Ni}-\mathrm{NiFe}_{2} \mathrm{O}_{4}-\mathrm{NiO}$ based anodes}

Liu et al. [10] conducted experiments on cermet anode of composition $15.3 \mathrm{wt} \% \mathrm{Cu}, 8.3 \mathrm{wt} \%$ $\mathrm{NiO}, 1.7 \mathrm{wt} . \% \mathrm{Ni}$ and $74.7 \mathrm{wt} . \% \mathrm{NiFe}_{2} \mathrm{O}_{4}$. The alloy is prepared in two steps: cold pressing and sintering the powdered form of all the materials. The aluminium electrowinning was performed at $960{ }^{\circ} \mathrm{C}$. It was observed that only $\mathrm{NiFe}_{2} \mathrm{O}_{4}$ layer was formed on the outer surface whereas $\mathrm{NiO}$ layer was expected to be formed on the anode. As the time progressed, the $\mathrm{NiFe}_{2} \mathrm{O}_{4}$ layer was becoming thicker which might be the reason for the disappearance of $\mathrm{NiO}$ layer. To find the corrosion behaviour of the anode, the purity of electrolyte and produced aluminium was checked. It was observed that the $\mathrm{Cu}$ was dissolved rapidly in the electrolyte whereas no traces of $\mathrm{Ni}$ and $\mathrm{Fe}$ were observed in the electrolyte. Reducing the percentage of $\mathrm{Cu}$ can reduce the corrosion rate but at the same time decreases the electrical conductivity of the anode. Much research has to be conducted to improve the anodic properties.

\section{3. $\mathrm{NiFe}_{2} \mathrm{O}_{4}-\mathrm{Cu}$ based anodes}

Tian et al. [9] prepared a cermet anode of two phases, $\mathrm{NiFe}_{2} \mathrm{O}_{4}$ and $\mathrm{Cu}$. The copper metal was added to increase the electrical conductivity and maintain the mechanical stability. Two anodes with different compositions were made, $\mathrm{NiFe}_{2} \mathrm{O}_{4}-5$ wt.\% $\mathrm{Cu}$ and $\mathrm{NiFe}_{2} \mathrm{O}_{4}-20$ wt.\% $\mathrm{Cu}$. The effects of preparation method on the physical structure and anodic properties were studied. The desired phase composition on the anodic surface can be obtained by controlling the oxygen's partial pressure between the decomposition oxygen pressures of $\mathrm{NiO}$ and $\mathrm{Cu}_{2} \mathrm{O}$. High relative density of the anode can be obtained by increasing the sintering time and temperature. The preparation process of the anode was difficult due to the low melting point and poor wetting characteristics of copper when it is combined with $\mathrm{NiFe}_{2} \mathrm{O}_{4}$. The sintering temperature of anode with $20 \mathrm{wt} . \% \mathrm{Cu}$ was $1000{ }^{\circ} \mathrm{C}$ whereas for $5 \mathrm{wt} . \% \mathrm{Cu}$ in the alloy, sintering can be performed at $1250{ }^{\circ} \mathrm{C}$. Decreasing the metal content in the anode increases the sintering temperature, but at the same time reduces the electrical conductivity of the anode. By adding metals such as $\mathrm{Ni}$ and $\mathrm{Co}$ which has high melting point and good wetting characteristics when alloyed with $\mathrm{NiFe}_{2} \mathrm{O}_{4}-\mathrm{Cu}$ alloy results in a good relative density of the alloy also sintering can be performed at high temperatures which helps to reduce the porosity of the anode.

\section{4. $\mathrm{Cu}_{2} \mathrm{O}-\mathrm{Cu}$ based anode}

$\mathrm{A} \mathrm{Cu}_{2} \mathrm{O}-\mathrm{Cu}$ cermet anode was tested by Feng et al. [25], they stated that the anode is partially inert and can be used to produce $\mathrm{Al}$ alloy and $\mathrm{Al}$ with little impurities of $\mathrm{Cu}$. There is more demand for $\mathrm{Al}$ alloys than pure Aluminium, which increases the importance of this kind of anodes. $\mathrm{This} \mathrm{Cu}_{2} \mathrm{O}-\mathrm{Cu}$ cermet anode was tested for its thermal corrosive behaviour in $\mathrm{Na}_{3} \mathrm{AlF}_{6}-\mathrm{AlF}_{2}-\mathrm{Al}_{2} \mathrm{O}_{3}$ electrolyte at 
$960{ }^{\circ} \mathrm{C}$ for different geometrical structures of $\mathrm{Cu}$ phase. A passive layer of $\mathrm{CuAlO}_{2}$ was observed on the anodic surface while performing SEM and the $\mathrm{CuAlO}_{2}$ layer thickness and density were increased with increasing corrosion time. It was stated that that the density and thickness of the layer were increased rapidly in the initial stages of the electrolysis process but was later slowed down as the time progressed. As the $\mathrm{Cu}$ content in the anode increased, the thermal corrosion rate also increased i.e. at $10 \mathrm{wt} . \%$ of $\mathrm{Cu}$ in the anode, the thermal corrosion rate was $0.68 \mathrm{mg} / \mathrm{cm}^{2} \mathrm{~h}$, whereas at $35 \mathrm{wt} . \%$ of Cu in the anode, the thermal corrosion rate was about $2.63 \mathrm{mg} / \mathrm{cm}^{2} \mathrm{~h}$. Also, the grain size of the $\mathrm{Cu}$ particles effect the thermal corrosion rate( directly proportional). The researchers stated that the ideal content of $\mathrm{Cu}$ would be $25 \mathrm{wt} . \%$ where the thermal corrosion rate of $1.5-7.2 \mathrm{mg} / \mathrm{cm}^{2} \mathrm{~h}$ and less than $6.3 \mathrm{wt} . \%$ of Cu content in the produced aluminium was observed. Researcher's state that this type of anodes will gain demand in the near future as the demand for aluminium alloy is more than pure aluminium.

\section{5. $\mathrm{Ni}\left(\mathrm{NiFe}_{2} \mathrm{O}_{4}-10 \mathrm{NiO}\right)$ based anode}

The corrosion behaviour of $17 \mathrm{Ni}\left(\mathrm{NiFe}_{2} \mathrm{O}_{4}-10 \mathrm{NiO}\right)$ cermet anode was tested by TIAN et al. [26]. The anode was prepared at different sintering atmospheric conditions and the electrolysis was conducted in $\mathrm{Na}_{3} \mathrm{AlF}_{6}-\mathrm{Al}_{2} \mathrm{O}_{3}$ electrolyte melt. The anode prepared in the atmosphere with oxygen content of $2 * 10^{-3}$ possessed corrosion rate of $2.71 \mathrm{~cm} / \mathrm{a}$ whereas anode prepared in a vacuum has a corrosion rate of about $6.46 \mathrm{~cm} / \mathrm{a}$. A thickness of densification layer of $50 \mu \mathrm{m}$ was recorded when the anode was prepared atatmosphere with oxygen content of $2 * 10^{-3}$ and in the case of anode prepared in the vacuum, the densification thickness layer of $30 \mu \mathrm{m}$ was observed. Also, the decrease of oxygen content in the sintering atmosphere results in the increase of $\mathrm{NiO}$ and $\mathrm{Fe}(11)$ content in $\mathrm{NiFe}_{2 \mathrm{x}} \mathrm{O}_{4-\mathrm{y}-\mathrm{z}}$ which leads to the poor corrosion resistance of the material and rapid mass loss in the anode can be observed.

\section{Unconventional inert anode}

\subsection{Solid oxide fuel cell}

Research on inert anodes was mostly conventional type, but there was also attempts made to achieve unconventional anode. R.A. Rapp [13] designed a non-consumable solid oxide fuel cell-type anode for the aluminium electrowinning process. The anode consists of nickel tube (conductor), into which the combustible fuel is sent. The bottom surface of the anode is layered with the zirconia based $\mathrm{O}^{2-}$ conducting electrolysis. When power is supplied, oxidation of combustible fuel occurs resulting in the evolution of oxygen as a primary anodic process. Figure 1 shows the working principle of SOFC type anode.

R.A. Rappclaimed that the SOFC type anode can be retrofitted in the present Hall-Heroult cell without any changes in the cell geometry and claimed that the cell would possess all the mandatory anodic properties. Later stages of research revealed that the zirconia layer inthe anode is easily soluble at high temperature cryolite melt leading to zirconia layer depletion.

\subsection{Bipolar electrodes}

Making bipolar electrodes for the industrial aluminium reduction cell has been the ultimate goal for the researchers. Bipolar electrode consists of both anode and cathode with an insulator separating them. Few advantages can be acquired by using a bipolar electrode like the geometry of the cell 


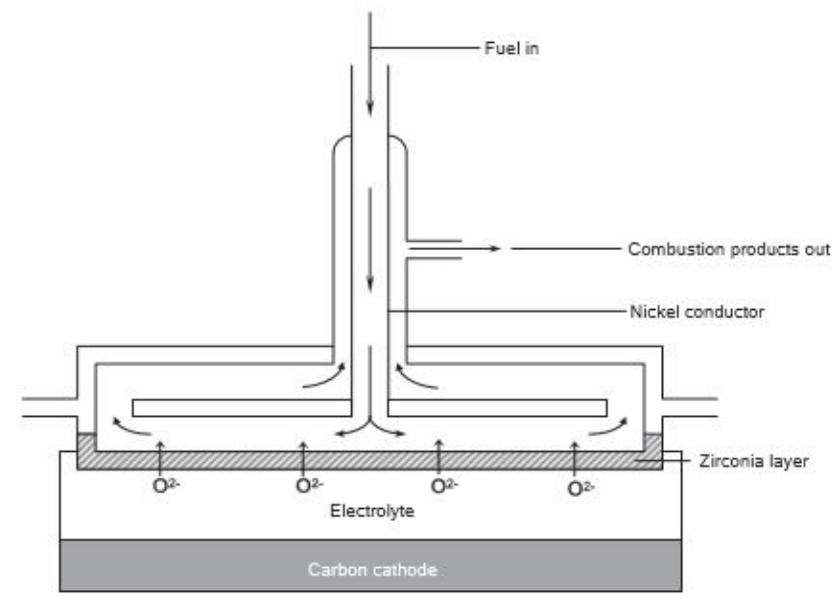

Fig. 1. Schematic diagram of Solid Oxide Fuel Cell

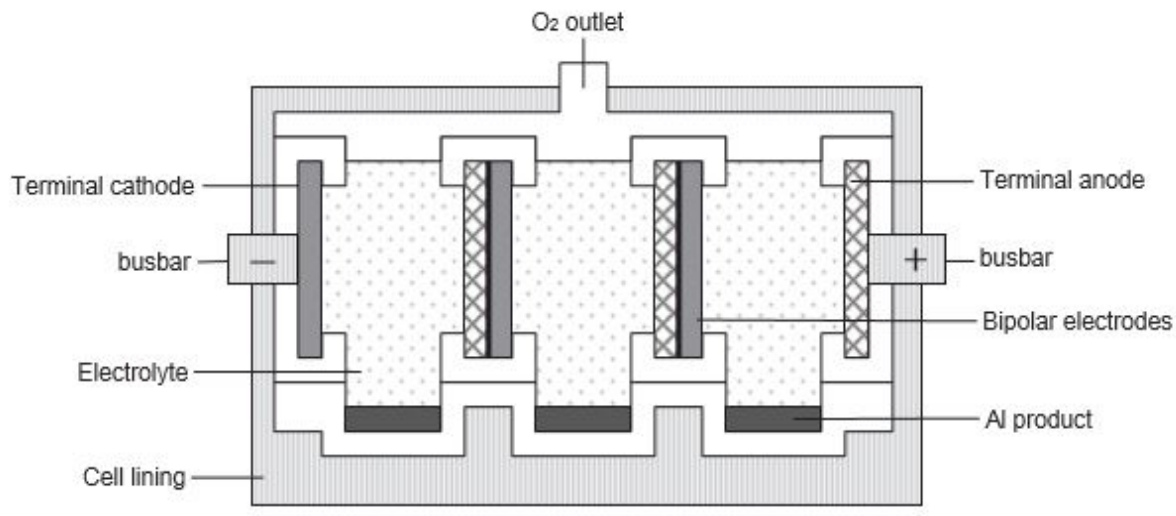

Fig. 2. Schematic diagram of the cell containing abipolar electrode

can be reduced, amount of electricity used in electrolysis process can be reduced drastically, and cell maintenance cost can be reduced. Swiss aluminium patented the first bipolar electrode for the Hall Heroult's cell in 1976 [21]. In the patent, they mentioned that the cell would contain two bipolar electrodes consisting of $\mathrm{SnO}_{2}+\mathrm{Sn}_{2} \mathrm{O}_{3}+\mathrm{CuO}$ anode layer and graphite cathode and an intermediate nickel layer which separates anode and cathode. They are made by pressing the three layers at high temperature (Fig. 2).

Many other bipolar anodes were patented, e.g. cermet anode (tin oxide with additives like zin oxide, antimony oxide and or vanadium oxide) and Titanium boride cathode. But none of the bipolar anodes have shown impact on the industrial cell.

\subsection{Depolarised gas anode}

Haarberg et al [24] came up with a depolarised gas anode. The necessity of this idea arises due to the fact that when the inert anodes are used in the aluminium electrowinning, reaction (2) takes place with Gibbs energy of $1283.316 \mathrm{~kJ} / \mathrm{mol}$ at $960^{\circ} \mathrm{C}$ and also decomposition overvoltage rises by $1 \mathrm{~V}$ than 


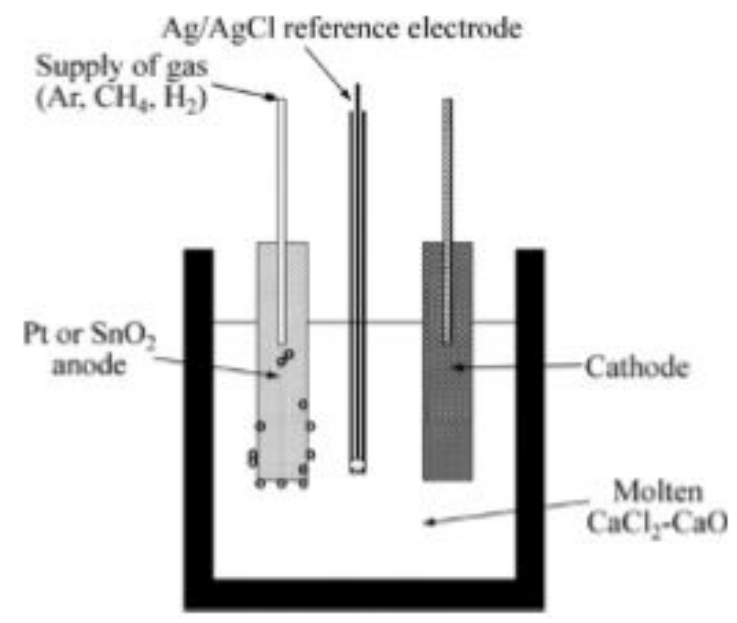

Fig. 3. Schematic diagram of Depolarised gas anode

that when the inert anode is used. The reduction of the ohmic voltage in the electrolyte can be attained by redesigning the cell. The $\mathrm{CO}_{2}$ produced at the anode can also be reduced by using an oxidizable gas which can depolarise the anodic process. In the experimental process, the electrolyte used is the molten $\mathrm{CaCl}_{2}$ with $\mathrm{CaO}$ and an additive of $\mathrm{AgCl}$ is added to the electrolyte to control the cathodic reaction (Fig. 3).

Two different anodes were tested with two different materials, one being a metal Platinum and the other being a ceramic Tin Oxide. The reference electrode was $\mathrm{Ag} / \mathrm{AgCl}$ to calculate the overvoltage of the anode. An experiment was conducted in an atmosphere of dry argon to avoid and eliminate the contamination of air from moisture and oxygen. The methane and hydrogen gas are supplied into the anode during the electrolysis process and reaction(3) takes place when methane is supplied and reaction(4), when hydrogen is supplied.

$$
\begin{aligned}
& \frac{1}{2} \mathrm{Al}_{2} \mathrm{O}_{3}(\text { diss })+\frac{3}{8} \mathrm{CH}_{4}(g)=\mathrm{Al}(l)+\frac{3}{8} \mathrm{CO}_{2}(g)+\frac{3}{4} \mathrm{H}_{2} \mathrm{O}(g) \\
& \frac{1}{2} \mathrm{Al}_{2} \mathrm{O}_{3}(\text { diss })+\frac{3}{2} \mathrm{H}_{2}(g)=\mathrm{Al}(l)+\frac{3}{2} \mathrm{H}_{2} \mathrm{O}(g)
\end{aligned}
$$

The behaviour of inert anodes of tin oxide and platinum was studied in separate experiments. The laboratory studies state that when hydrogen is introduced into the anode during the electrolysis process, a significant amount of anodic potential was lowered (0.3-0.5 V) while using platinum anode. While using Tin oxide, $0.1 \mathrm{~V}$ of anodic potential was lowered. Both the anodes showed potential and further improvements should be made.

\section{Anode design}

The geometry of the anode plays a vital role in its performance. Only metallurgical properties of the anode were focused and very less attention was given to the mechanical properties of the anode. Antille et al. [26] discussed the engineering related to the industrial-scale de Nora anodes for a $25 \mathrm{kA}$ test cell. Computer modelling was used to simulate the electrical and hydrodynamic behaviour of the anodes with different geometries. 


\subsection{Oxygen gas flow}

The oxygen gas evolved at the anodic surface has to be removed quickly as soon as it is evolved to reduce the corrosion rate of the anode. Oxidation on the anodic surface takes place and leads to corrosion if the oxygen produced on the surface of the anode stays in contact with it for a longer time. Slotted anodes containing cylindrical bars are preferred rather than monolithic anode blocks, as the gas escape quickly from the surface of slotted anodes and the statement was supported by Sides and Prentice [27], where they conducted tests and found that approximately $0.4 \mathrm{~V}$ of voltage is saved when slotted anodes are used. It is also stated that when anodes are inclined, the gas escape quickly from the surface of the anode and the bubble size is less.

\subsection{Current density distribution}

The anodic life is expected to be less when the anodic current density is higher and the anodes with lower anodic current density is advisable. The anodic current density of circular cross-section anode and triangular cross-section anode were measured and it was found that the current density of circular cross-section was high compared to that of triangular cross-section anode but it was also observed that the edges of the triangular cross-section anode possesses higher current density. So, it is advisable to have an anodic geometry somewhere between circular and triangular.

\section{Future scope}

In the past, many research organisations claimed that the inert anodes will be used in industrial cells by 2020 , but still the difficulty of inventing an ideal inert anode is in process. A lot scientist and research organisations are considering to make an advanced cell prototype which will be able to retrofit the inert anodes without any obstacles. La Camera [22] came up with vertical bipolar electrode and cathode being highly wettable. Many of laboratory scale anodes have showed some promising performance and effects are madeto transform them into industrial scale cells as anodes. Polyakov et al [23, 28-32] have been investigating on novel electrolysis process for aluminium production, in which slurry is used an electrolyte, where electrodes are placed vertical and interelectrode spacing is minimal which results in high electrical conductivity in comparison with presently developed inert anodes technologies. The research is still in initial stage and is expecting to see some promising results in the nearest future.

\section{Conclusion}

A lot of research has been done till date and is still continued to attain ideal inert anode. Electrical conductivity,oxidation behaviour and thermal shock resistance of three different types of anodes were studied. MolTech has achieved success and claim to use inert anode already in a smaller scale cell. De Nora anode of MolTech showed promising results and claims that the anode would have a lifetime of nearly 2 years. Alcoa has completely stopped it's the research towards inert anodes. Few anodes showed good results with Fluoride electrolyte when the electrolysis process was performed at low temperature $\left(700^{\circ} \mathrm{C}\right)$. Alcoa came up with cermet anodes which showed good electrical conductivity and high oxidation resistance but had a problem of low thermal shock resistance and electrical connections between the anode and the busbar was complicated. Corrosion rate of the anode can be reduced by preparing the anode at high sintering temperature and time [4]. R.A. Rapp came up with novel oxygen 
evolving anode, but the anode failed to perform. Kvande and Haupin [19] and Sadoway [20] argue that even after finally achieving an inert anode, the process of retrofiting the anode into traditional cell would be difficult task. Researchers are trying to achieve new aluminium electrolysis process which is still in initial stage. Inert anodes not only eliminate the formation of greenhouse gases but also increase current efficiency of the cell and are economically advantageous. Nevertheless, industries and research organisations believe that inert anodes can be prepared and used in the nearest future.

\section{Acknowledgments}

The reported study was funded by Russian Foundation for Basic Research, Government of Krasnoyarsk Territory, Krasnoyarsk Region Science and Technology Support Fund to the research project № 16-43-240781.

The article is based on the paper presented at the IX International Congress "Non-ferrous metals and minerals-2017".

\section{References}

1. de Nora V. Inert anodes are knocking at the door of aluminium producers. CRU annual meeting, London, 26 June 2001.

2. Du J., Wang B., Liu Y., Yao G.C., Fang Zh., Hu P. Study on the bubble behaviour and anodic overvoltage of $\mathrm{NiFe}_{2} \mathrm{O}_{4}$ ceramic based inert anode. Light Metals 2015. P. 1193-1197.

3. Augustin C., Sen U.A. Green anode for aluminium production. Incal'98. International Conference on Aluminium, New Delhi, 11-13 Feb. 1998. Vol. 2, P. 173-176.

4. Patent 3960678US. Alder H. Electrolysis of a molten charge using incomsumable electrodes. Publ. Date. 1.06.1976.

5. Haarberg G.M. The interaction between tin oxide and cryolite-alumina melts. 9th Int. Symp. on Molten Salts. San Francisco, USA, 22-27 May 1994, P. 568-577.

6. Zaikov Yu.P. et al. Ceramic properties of electrodes based on Ni0-Li20 and their solubility in cryolite alumina melts. Vill. AI Sympozium, 25-27 Sept. 1995. Slovakia, ZiarnadHronom-Donovaly, P. 239-241.

7. Patent 4454015US. Ray S.P. and Rapp R.A. Composition suitable for use as inert electrode having good electrical conductivity and mechanical properties. Publ. Date. 12.06.1984.

8. Patent 4584172US. Ray S.P. and Rapp R.A. Method of making composition suitable for use as inert electrode having good electrical conductivity and mechanical properties. Publ. Date. 22.04.1986.

9. Tian Zh.-L., Lai Y.-Q., Gang Zh., Qing-Wei Q., Jian-feng W., Jie L., Ye-xiang L. Preparation of $\mathrm{NiFe}_{2} \mathrm{O}_{4}-\mathrm{Cu}$ based cermet inert anodes in aluminium electrolysis. The Chinese Journal of Nonferrous Metals 2003. Vol. 13 (6), P. 1540-1545.

10. Liu J.-Y., Li Zh.-Y., Tao Y.-Q., Zhang D., Zhou K.-Ch. Phase evolution of 17(Cu-10Ni)$\left(\mathrm{NiFe}_{2} \mathrm{O}_{4}-10 \mathrm{NiO}\right)$ cerment inert anode during aluminium electrolysis. Transaction of Non-ferrous metals in China 2011. Vol. 21 (3), P. 566-572.

11. Glucina M., Hyland M. Laboratory scale testing of Aluminium Bronze as an Inert anode for Aluminium Electrolysis. Light Metals 2005. P. 523-528.

12. Nguyen Th., de Nora V. de Nora Oxygen evolving inert metallic anode. Light Metals 2006, P. 385-390. 
13. Patent 6039862US. Rapp R.A. Method featuring a non-consumable anode for the electrowinning of aluminium. Publ. Date. 21.03.2000.

14. Simakov D.A. et al. Progress in the development of reduction technology with inert anodes. Proc. Non Ferrous Metals2012. P. 363.

15. Helle S., Pedron M., Assouli B., Davis B., Guay D., Roue L. Structure and hightemperature oxidation behaviour of $\mathrm{Cu}-\mathrm{Ni}-\mathrm{Fe}$ based alloys prepared by high energy ball milling for application as inert anodes for aluminium electrolysis. Corrosion Science 2010. Vol. 52(10), P. 3348-3355.

16. Helle S., Tresse M., Guay D., Roue L. Mechanically alloyed Cu-Ni-Fe-O based materials as oxygen evolving anodes for aluminium electrolysis. Journal of Electrochemical society 2012. Vol. 159(4), P. 62-68.

17. Divinshi S.V., Herzig C., Hisker F., Filipek R., Danielewski M. Self and interdiffusion in Ternary Cu-Fe-Ni alloys. Defects and Diffusion forum 2005, P. 237-240.

18. Gavrilova E., Goupil G., Davis B., Guay D., Roue L. Influence of Partial substitution of Cu by various elements in $\mathrm{Cu}-\mathrm{Ni}-\mathrm{Fe}$ alloys on their high temperature oxidation behaviour. Light Metals 2015, P. 1187-1191.

19. Kvande $\mathrm{H}$. and Haupin W. Inert anodes for aluminium smelting: energy balances and environmental impact. JOM 2001. Vol. 53 (5), P. 29-33

20. Sadoway D.R. Inert anodes for the Hall-Heroult cell: the ultimate materials challenge. JOM 2001. Vol. 53(5), P. 34-35.

21. Patent 3930967 US. Alder H. Process for the electrolysis of a molten charge using inconsumable bi-polar electrodes. Publ. Date. 6.01.1976.

22. Patent 5415742A US. Lacamera A.F. et al. Process and apparatus for low temperature electrolysis of oxides. Publ. Date. 16.05.1993.

23. Polyakov P.V., Klyuchantsev A.B., Yasinskiy A.S., Popov Y.N. Conception of "Dream Cell” in aluminium electrolysis. Light Metals 2016, P. 283-288.

24. Haarberg G.M., Kvalheim E., Ratvik A.P., Xiao S.J., Mokkelbost T. Depolarised gas anodes for aluminium electrowinning. Trans. Nonferrous Met. Soc. China 2010. Vol. 20, P. 2152-2154.

25. Feng L.-Ch., Xie N., Shao W.-Zh., Zhen L., Ivanov V.V. Exploring $\mathrm{Cu}_{2} \mathrm{O} / \mathrm{Cu}$ cermet as a partially inert anode to produce aluminium in a sustainable way. Journal of alloys and compounds 2014. Vol. 610, P. 214-223.

26. Antille J., Klinger L., von Kaenel R., de Nora V. Modeling of a 25 kA de Nora Inert Metallic Anode Test Cell. Light Metals 2006, P. 391-396.

27. Sides P.J., Prentice G.A. The Effect of Electrode Shape on the Cell Voltage of Hall Cells, II. Inert Anodes. Electrochim. Acta 1988. Vol. 33, P. 1043.

28. Yasinskiy A.S., Vlasov A.A., Polyakov P.V., Solopov I.V. Impact of alumina partial density on the process conditions of aluminium reduction from cryolite-alumina slurry parameters. Tsvetnye Metally 2016. Vol. 12, P. 33-38.

29. Yasinskiy A.S., Polyakov P.V. Investigation of bubble behaviour at cryolite melt - alumina slurry electrolysis. Journal of Siberian Federal University. Engineering \& Technologies 2016. Vol. 9(6), P. $854-871$ 
30. Yasinskiy A.S., Polyakov P.V., Klyuchantsev A.B. Motion dynamics of anodic gas in the cryolite melt-alumina high-temperature slurry. Russian Journal of Non-Ferrous Metals 2017. Vol. 58(2). P. 109-113.

31. Nikolaev A.Yu., Yasinskiy A.S., Suzdaltsev A.V., Polyakov P.V., Zaikov Yu.P. Aluminium electrolysis in the $\mathrm{KF}_{-}-\mathrm{AlF}_{3}-\mathrm{Al}_{2} \mathrm{O}_{3}$ melts and suspensions. Raspalvy 2017. Vol. 3, P. 205-213.

32. Nikolaev A.Yu., Yasinskiy A.S., Suzdaltsev A.V., Polyakov P.V., Zaikov Yu.P. Voltammetry in the $\mathrm{KF}_{-}-\mathrm{AlF}_{3}-\mathrm{Al}_{2} \mathrm{O}_{3}$ melts and suspensions. Raspalvy 2017. Vol. 3. P. 214-225. 